\title{
Spatial heterogeneity of soils of the Cerrado-Pantanal ecotone ${ }^{1}$
}

\author{
Heterogeneidade espacial dos solos de Cerrado, zona de ecótono com o Pantanal
}

\author{
Isabela Codolo de Lucena ${ }^{2 *}$, Ricardo Santos Silva Amorim³, Francisco de Almeida Lobo ${ }^{3}$, Raquel Negrão \\ Baldoni $^{2}$ e Dalva Maria da Silva Matos ${ }^{4}$
}

\begin{abstract}
In areas of the Cerrado-Pantanal ecotone in Brazil, the soil displays features which are inherent to the processes of soil formation, both of the Central Plateau and the Pantanal Plain. Given this premise, the area should be noteworthy for its high level of edaphic heterogeneity. The present study aimed to determine the physical, chemical and physico-hydric attributes that best explain the heterogeneity of soils in areas of the Cerrado-Pantanal ecotone, and to assess whether these attributes differ between the studied fragments and between the Cerrado soils of the Central Plateau and of the Pantanal Plain. One hundred and sixty soil samples were collected and 11 profiles described for five areas of the Cerrado-Pantanal ecotone ( $15^{\circ} 43^{\prime}$ S , 56 $04^{\circ}$ ' W). The following classes were identified: typic Concretionary Petric Plinthosol; typic Lithoplintic Petric Plinthosol; typic dystrophic Yellow Latosol; dystrophic Yellow Latosol with plinthite, the last three not yet having been described for this region. The chemical attributes CEC, M, OM, K, P, Mg, $\mathrm{Ca}$ and $\mathrm{Mn}$ explained $40.49 \%$ of the variability of the soils in the region under study, whether differing or not between the studied fragments. Spatial distribution of the attributes varied between random and aggregated, with the chemical attributes CEC, K, Ca and Mg being similar to soils of the Pantanal Plain. Whereas Al, P and Mn, as well as the hydric variables, were similar to the Plateau. On the other hand, the average organic matter content, $\mathrm{pH}$, gravel and pebbles, were characteristic of both the Plateau and the Plain.
\end{abstract}

Key words: Physicochemical attributes. Geostatistics. Plinthosols. Latosols.

RESUMO - Nas áreas de Cerrado em zona de ecótono com o Pantanal, o solo apresenta características inerentes ao processo de formação dos solos tanto do Planalto Central quanto da Planície do Pantanal. Considerando tal premissa, esta área deve se destacar por sua elevada heterogeneidade edáfica. O presente estudo teve como objetivos determinar os atributos físicos, químicos e físico-hídricos que melhor explicam a heterogeneidade de solos em áreas de Cerrado, ecótono com o Pantanal, e avaliar se estes atributos diferem entre os fragmentos estudados e entre solos de Cerrado do Planalto Central e da Planície do Pantanal. Foram coletadas 160 amostras de solo e descritos 11 perfis em cinco áreas de Cerrado zona de ecótono com o Pantanal (154' S; 56 04' W). Foram identificadas as classes Plintossolo Pétrico Concrecionário típico, Plintossolo Pétrico Litoplíntico típico, Latossolo Amarelo distrófico típico e Latossolo Amarelo distrófico com plintita, sendo que as últimas três ainda não haviam sido descritas para esta região. Os atributos químicos CTC, H, M.O., K, P, Mg, Ca, Mn explicaram 40,49\% da variabilidade de solos da região em estudo, diferindo ou não entre os fragmentos estudados. A distribuição espacial dos atributos variou entre aleatória e agregada, sendo os atributos químicos CTC, K, Ca e Mg similares aos solos da Planície do Pantanal. Já o Al, o P e o Mn bem como as variáveis hídricas foram similares ao Planalto. Por outro lado, o teor médio de matéria orgânica, o pH, cascalho e calhaus foram característicos tanto do Planalto como da Planície.

Palavras-chave: Atributos físico-químicos. Geoestatística. Plintossolos. Latossolos.

\footnotetext{
*Autor para correspondência

${ }^{1}$ Recebido para publicação em 24/05/2013; aprovado em 24/06/2014

Parte da Tese da primeira autora na Universidade Federal de São Carlos, financiamento: CNPq

${ }^{2}$ Programa de Pós-Graduação em Ecologia e Recursos Naturais, Universidade Federal de São Carlos, São Carlos-SP, Brasil, isabelaclucena@ gmail.com, raquelnegrao@yahoo.com.br

${ }^{3}$ Departamento de Solos e Engenharia Rural, Universidade Federal de Mato Grosso, Cuiabá-MT, Brasil, rsamorim@ufmt.br, f_a_lobo@ufmt.br

${ }^{4}$ Departamento de Hidrobiologia, Universidade Federal de São Carlos, São Carlos-SP, Brasil, dmatos@ufscar.br
} 


\section{INTRODUCTION}

Natural resources are generally not evenly distributed spatially, and this environmental heterogeneity becomes a barrier to plants due to their sessile nature (POOR et al., 2005). The soil, an essential natural resource, is noteworthy due to its spatial heterogeneity, which maximizes the biodiversity of a particular ecosystem (POSSLEY; WOODMANSEE; MASCHINSKI, 2008) either through taxonomic, functional and genetic pedodiversity or because of the heterogeneity of the soil attributes (DUNIWAY; BESTELMEYER; TUGEL, 2010).

In the Cerrado regions of Brazil, detailing the soil attributes becomes a proven necessity due to chemical, physical and hydric variability. Studies show the variations in these attributes, with emphasis on aluminum saturation, acidity and organic matter content, and their relationship to soil fertility (ASSIS et al., 2011; NERI et al., 2012).

The Cerrado of the Cuiabana Depression presents a flattened terrain and greatly altered rocks, which generated a deposition of gravels arising from the breakdown of quartz veins (CASTRO JUNIOR; SALOMÃO; BORDEST, 2006). Due to peneplanation, this area resembles the Pantanal Formation, and has 18 classes of soil (SHINZATO; TEIXEIRA; MARTINS, 2006). However, due to the small map scale used, there are no records on the existence of other classes, nor the physical, chemical or hydro-physical heterogeneity of the topsoil (PROJETO DE DESENVOLVIMENTO AGROAMBIENTAL DO ESTADO DE MATO GROSSO, 2001; SHINZATO; TEIXEIRA; MARTINS, 2006). Part of this depression is formed by an ecotone. Ecotones consist of areas of environmental transition (KARK; VAN RENSBURG, 2006). In this environment marked changes in the soil can be identified which present inherent characteristics of the Cerrado of both the Plateau and Pantanal Plain.

In this study, results will be presented on the diversity of soils of an area of Cerrado of the Cuiabana Depression in an ecotone with the wetlands of the Pantanal. The aims were to: a) determine the physical, chemical and physico-hydric attributes that best explain the variability of the soil in this region; b) assess the spatial heterogeneity of these attributes; c) assess whether the classes and attributes found in the topsoil differ between soils of the Cerrado of the Central Plateau and those of the Pantanal Plain.

\section{MATERIAL AND METHODS}

The study was carried out on five fragments of the Cerrado-Pantanal ecotone in the Cuiabá Depression, inserted into a matrix of grassland (DATUM: SAD 69 $\left.15^{\circ} 43^{\prime} \mathrm{S}, 56^{\circ} 04^{\prime} \mathrm{W}\right)$. Fragmentation is characterised by a process of anthropic rupturing of the continuity of the landscape units. For the case under study, all the fragments are small (5.48 to $12 \mathrm{ha}$ ) and have been protected for about 20 years. Vegetation in the region has been classified as cerrado sensu stricto (COUTINHO, 1978). The climate in the region is of type Aw (KÖPPEN; GEIGER, 1928), with average monthly temperatures ranging between 22 and $27.2^{\circ} \mathrm{C}$ and an average annual rainfall of $1,320 \mathrm{~mm} \mathrm{yr}^{-1}$.

The perimeter of each fragment was delimited employing a GPS, model GPSMAP 76C (Garmin International, Inc., Olathe, KS, USA) and displayed with the Garmin Mapsource software (Garmin International, Inc., Olathe, KS, USA) which was used only for delineation and reconnaissance of the area. In the field, the entire perimeter of each fragment was divided into plots of $10 \times 10 \mathrm{~m}$. Thirty-two plots were selected in each fragment, and in each plot a sample of soil from 0 to $20 \mathrm{~cm}$ deep was collected following a method of restricted randomisation. This method allows a selection of points to be made within a predetermined sample space (GREIG-SMITH, 1983). In total 160 soil samples were collected, numbering 32 per fragment.

Spatial variability of the vegetation is indicative of changes in soil class (ASSIS et al., 2011). Thus, in order to describe the profiles, plots were selected for each fragment that showed the highest and lowest values for richness and abundance of any woody species with a diameter $\geq 3$ at $30 \mathrm{~cm}$ from the ground, with intermediate values being identified only for fragment 1. This gave a total of 11 soil profiles (Table 1). The geographic coordinates and altitudes of each soil sample were determined using a high precision GPS (TOPCON Hyper Lite FC 200). The soil profiles were described according to the Brazilian System of Soil Classification - SiBCS (EMPRESA BRASILEIRA DE PESQUISA AGROPECUÁRIA, 2006). The analyses of the physical and chemical attributes of the soil profiles were carried out according to Empresa Brasileira de Pesquisa Agropecuária (1997).

In soil samples collected at a depth of 0 to $20 \mathrm{~cm}$, chemical and physical attributes were determined according to Empresa Brasileira de Pesquisa Agropecuária (1997): potential hydrogen $(\mathrm{pH})$, phosphorus $\left(\mathrm{P}, \mathrm{mg} \mathrm{dm}^{-3}\right)$, potassium $\left(\mathrm{K}, \mathrm{cmol}_{\mathrm{c}} \mathrm{dm}^{-3}\right)$, calcium $\left(\mathrm{Ca}, \mathrm{cmol}_{\mathrm{c}} \mathrm{dm}^{-3}\right)$, magnesium $\left(\mathrm{Mg}, \mathrm{cmol}_{\mathrm{c}} \mathrm{dm}^{-3}\right)$, organic matter (OM, $\left.\mathrm{g} \mathrm{dm}^{-3}\right)$, sum of bases $\left(\mathrm{S}, \mathrm{cmol}_{\mathrm{c}} \mathrm{dm}^{-3}\right)$, cation exchange capacity $\left(\mathrm{T}, \mathrm{cmol}_{\mathrm{c}} \mathrm{dm}^{-3}\right)$, base saturation $(\mathrm{V} \%)$, exchangeable aluminum $\left(\mathrm{Al}, \mathrm{cmol}_{\mathrm{c}} \mathrm{dm}^{-3}\right)$, hydrogen $\left(\mathrm{H}, \mathrm{cmol}_{\mathrm{c}} \mathrm{dm}^{-3}\right)$, zinc $\left(\mathrm{Zn} \mathrm{mg} \mathrm{kg}{ }^{-1}\right)$, copper $\left(\mathrm{Cu}, \mathrm{mg} \mathrm{kg}^{-1}\right)$, iron (Fe mg kg ${ }^{-1}$ ), manganese $\left(\mathrm{Mn} \mathrm{mg} \mathrm{kg}^{-1}\right)$, boron ( $\mathrm{B} \mathrm{mg} \mathrm{kg}^{-1}$ ), sulphur ( $\mathrm{S} \mathrm{mg} \mathrm{kg}^{-1}$ ), fine air-dried earth (FADE $\mathrm{g} \mathrm{kg}^{-1}$ ), gravel 
Table 1 - Selected location for the description of soil profiles, altitude (m), abundance (No. of individuals $\mathrm{m}^{-2}$ ) and richness (No. of species $\mathrm{m}^{-2}$ ) in five fragments of Cerrado-Pantanal ecotone

\begin{tabular}{|c|c|c|c|c|c|}
\hline \multirow{2}{*}{ Fragment } & \multicolumn{2}{|c|}{--------------------UTM---------------------- } & \multirow{2}{*}{ Altitude } & \multirow{2}{*}{ Abundance } & \multirow{2}{*}{ Richness } \\
\hline & $\mathrm{N}(\mathrm{m})$ & $\mathrm{E}(\mathrm{m})$ & & & \\
\hline 1 & 599731 & 8261500 & 182.30 & 61 & 25 \\
\hline 1 & 599838 & 8261439 & 184.81 & 35 & 17 \\
\hline 1 & 599775 & 8261551 & 182.35 & 25 & 16 \\
\hline 2 & 599801 & 8260429 & 189.95 & 46 & 17 \\
\hline 2 & 599936 & 8260463 & 183.93 & 38 & 9 \\
\hline 3 & 598750 & 8260896 & 170.25 & 62 & 12 \\
\hline 3 & 598806 & 8260864 & 178.57 & 19 & 7 \\
\hline 4 & 597964 & 8261428 & 173.11 & 37 & 17 \\
\hline 4 & 598040 & 8261476 & 172.65 & 17 & 10 \\
\hline 5 & 597113 & 8261555 & 173.09 & 35 & 18 \\
\hline 5 & 597044 & 8261600 & 171.25 & 17 & 10 \\
\hline
\end{tabular}

$\left(\mathrm{Gr}, \mathrm{g} \mathrm{kg}^{-1}\right)$ and pebbles $\left(\mathrm{Pe}, \mathrm{g} \mathrm{kg}^{-1}\right)$, as well as silt $\left(\mathrm{s}, \mathrm{g} \mathrm{kg}^{-1}\right)$, clay $\left(\mathrm{cl}, \mathrm{g} \mathrm{kg}^{-1}\right)$ and sand $\left(\mathrm{sa}, \mathrm{g} \mathrm{kg}^{-1}\right)$ obtained from the airdried soil (FADS $\mathrm{g} \mathrm{kg}^{-1}$ ). To determine the field capacity (FC), permanent wilting point (PWP) and plant available water (PAW), seven collection points were selected based on the variation of clay content in the area (103, $134.4,160,190.4,210.4,250$ and $296 \mathrm{~g} \mathrm{~kg}^{-1}$ ), since this content directly affects the hydro-physical behaviour of the soil. The FC was determined employing soil column drainage, and the PWP using the soil water retention curve equivalent to the soil moisture retained at a pressure of $15 \mathrm{~atm}$. As the soil of the Cuiabana Depression shows a high percentage of pebbles $(9.1 \% \pm 11.25)$ and gravel $(32.8 \% \pm 24)$, the values for FC and PWP were corrected for the actual percentage of fine air-dried earth (FADE) of each sample, by using equations 1 and 2 :

$$
\begin{aligned}
& \frac{P W P_{\text {actual }}=P W P-F A D E}{100} \\
& \frac{F C_{\text {actual }}=F C-F A D E}{100}
\end{aligned}
$$

where: PWP - soil moisture equivalent to the permanent wilting point, obtained for a sample of $100 \%$ fine earth; FC - soil moisture equivalent to field capacity, obtained for a sample of $100 \%$ fine earth; FADE actual percentage of fine earth in the sample.

The plant available water was obtained by the difference between $\mathrm{FC}_{\text {actual }}$ and $\mathrm{PWP}_{\text {actual }}$.
These variables were estimated for the remaining collection points in the topsoil, using equations 3 and 4 respectively, obtained by Lucena et al., (unpublished):

$F C_{\text {actual }}(\%)=11.625+(-0.353$ pebbles $) R^{2}=0.94$

$P W P_{\text {actual }}(\%)=2.94+\left((-0.107\right.$ pebbles $)+(0.139$ silt $) \quad R^{2}=0.94$

The SPSS 17.0 software (SPSS, Inc., Chicago, IL, USA) was used to perform the factor analysis with varimax rotation and Kaiser normalisation. It was thus possible to sort the variables into a small group of factors that represented the maximum variation present in the soil. Variables with eigenvalues $>0.6$ and a cumulative variance close to $70 \%$ were considered. This criterion was determined according to analysis of the factorial matrix. The criteria for inclusion of a factor were those items that exhibited high loads for their own characteristics and low loads for the remaining facets. To this end, the number of factors was defined by that point at which an additional factor would represent a lower variance than a typical variable, i.e. an eigenvalue.

To evaluate spatial distribution of the soil variables, the coordinates $(x, y)$ and factor coefficients were used. For this the method of Spatial Analysis by Distance Indices was employed, using the SADIEShell version 1.22 statistical software (Rothamsted Research, Harpenden, UK). The aggregation index was obtained: $\mathrm{Ia}=1$ and $\mathrm{p}>0.05$ indicate random distribution; Ia $>1$ and $\mathrm{p}<0.05$, aggregated distribution; Ia $<1$ and $\mathrm{p}>0.95$, uniform ditribution. In all the analyses carried out, a 
total of 30,000 permutations were employed. From the results of similarity, maps of the aggregation indices were produced with the Surfer version 8.0 software (Golden Software, Inc., Golden, CO, USA), using the kriging method for interpolation of the aggregation indices generated by the SadieShell software. To evaluate whether those variables that make up the factors differed between fragments, the permutation $\mathrm{t}$ test $(\mathrm{N}=1,000)$ was used. A review of the literature enabled comparison of the average values of the soil properties in the study area with those of the Plateau and Pantanal Plain.

\section{RESULTS AND DISCUSSION}

The results revealed the occurrence of three new classes for this region, dystrophic Yellow Latosol, dystrophic Yellow Latosol with plinthite and typic Lithoplintic Petric Plinthosol (Table 2). In this same area, only the Red Yellow Latosol and Petric Plinthosol classes had been identified on the scale of 1:100,000 (SHINZATO; TEIXEIRA; MARTINS, 2006), and the Red Yellow Latosol and dystrophic Concretionary Podzolic classes on the scale of 1:250,000 (PROJETO DE DESENVOLVIMENTO AGROAMBIENTAL DO ESTADO DE MATO GROSSO, 2001).

Fragments 1, 3 and 4 were made up of Plinthosols varying for the 3rd level of classification (Table 2). These soils presented ferruginous concretions, susceptible to flooding, similar to the Pantanal Plain and the Brazilian Central Plateau. Plinthosols with a plinthic horizon occur in floodplains, in areas with flat or gently rolling terrain in geomorphic depression zones or those conditioned by oscillations in the water table (EMPRES BRASILEIRA DE PESQUISA AGROPECUÁRIA, 2006). On the other hand, Plinthosols having a concretionary horizon display better drainage and occupy slightly higher elevations than do the Plinthic Plinthosols. The occurrence of Plinthosols associated with ramped surfaces favours runoff (SHINZATO; TEIXEIRA; MARTINS, 2006), similar to that described by Beirigo (2008) for mountainous terrain consisting of Plinthosols along the floodplain of the Pantanal. Plinthosols normally occur in the sources of water courses (LACERDA; BARBOSA, 2012; NASCIMENTO 2012; SCHIAVO et al., 2010).

Latosols were identified in fragments 2, 3 and 5 with variations for the 4th and 5 th level of classification (Table 2). Similar to recorded in the study area, the occurrence of a typic Dystrophic Yellow Latosol was also described in the Federal District and in the region of Dom Aquino, on the borders of the Guimarães Plateau in the state of Mato Grosso (MT), and of a dystrophic Petroplinthic Yellow Latosol in the Cerrado of the Federal District (LACERDA; BARBOSA, 2012). As described for a Petroplithic Latossol in the Cerrado of the Federal District, this type of soil is characterised by a large amount of concretion throughout the profile (clay, kaolinite, goethite among other minerals), by stones and by the chemical limitations inherent to Latosols (LACERDA; BARBOSA, 2012).

The identification of new classes of soil, together with other previously-identified classes (PROJETO DE DESENVOLVIMENTO AGROAMBIENTAL DO ESTADO DE MATO GROSSO, 2001; SHINZATO; TEIXEIRA; MARTINS, 2006), helps when describing edaphic heterogeneity in areas of the Cerrado-Pantanal ecotone. This heterogeneity of the environment may be the factor that maximizes the biodiversity (POSSLEY; WOODMANSEE; MASCHINSKI, 2008) and functions in an ecosystem (ZEITHAML; PIZL; SKLENICK, 2009). The occurrence of concretionary soils, such as Plinthosols, is restricted to areas susceptible to flooding and where drainage is impeded, as in the Pantanal Plain of Mato Grosso and the Brazilian Central Plateau, where concretionary soils may also be associated with Latosols. A dystrophic yellow Latosol has powerful drainage and low cation exchange capacity. However the presence of plinthite reduces the available water being drained into the marsh plains. In the same study area, these soils are associated with Plinthosols, a class consisting of different physical and chemical characteristics, which increases variability in the edaphic conditions of the environmental ecotone under study.

From the factor analysis it was found that the first four factors explained $70.61 \%$ of the cumulative variance (Table 3). Together with these four factors, 16 topsoil variables with eigenvalues $>0.6$ were selected, with the highest variability being identified in the chemical variables that characterise soil fertility, in accordance with factor 1 (Table 3 ).

The spatial distribution was both random and aggregated for the four factors (Table 4). The random distribution indicates the absence of any spatial dependence, while the aggregated distribution confirms the spatial dependence of any one given factor. This result may be related to the intrinsic properties of the soil, which is under the influence of both the Pantanal and the Cerrado. For factor 1 (CEC, H, OM, K, P, Mg, Ca and $\mathrm{Mn}$ ), all variables are positively correlated (Table 3), with a random and aggregated spatial distribution (Table 4). As an example of both types of spatial distribution, maps of fragment 1 are shown (Figure 1). The lighter areas 
Table 2 - Classes and soil attributes in fragments of the Cerrado-Pantanal ecotone

\begin{tabular}{|c|c|c|c|c|c|c|c|c|c|c|c|c|c|c|c|c|c|c|c|}
\hline F & Soil class & Hzn & $\frac{\text { Depth }}{(\mathrm{cm})}$ & $\frac{\text { Colour }}{\text { (humid) }}$ & $\mathrm{Pe}$ & $\mathrm{Gr}$ & FADE & sa & $\mathrm{s}$ & $\mathrm{cl}$ & $\mathrm{pH}$ & $\mathrm{Ca}+\mathrm{Mg}$ & $\mathrm{K}$ & $S$ & $\mathrm{Al}^{3+}$ & $\mathrm{H}^{+}$ & $\mathrm{T}$ & V & $\mathrm{P}$ \\
\hline 1 & Typic FFlf & A & $0-31$ & $10 \mathrm{YR} 4 / 6$ & 0 & 9.2 & 90.8 & 737 & 20 & 243 & 4.6 & 0.3 & 0.2 & 0.4 & 1.3 & 2.9 & 4.5 & 8.8 & 2 \\
\hline 1 & Typic FFlf & Ac & $0-17$ & $10 \mathrm{YR} 3 / 3$ & 6 & 66.7 & 27.3 & 830 & 20 & 150 & 5 & 1.6 & 0.2 & 1.9 & 0.4 & 5.9 & 8.2 & 23.3 & 9.1 \\
\hline \multirow{3}{*}{1} & \multirow{3}{*}{ Typic FFc } & Ac & $0-18$ & 7,5 YR 4/4 & 3.5 & 18.7 & 77.8 & 670 & 119 & 211 & 4.6 & 1 & 0.2 & 1.2 & 0.8 & 3.9 & 5.9 & 20 & 3.6 \\
\hline & & Bcf1 & $18-59$ & $10 \mathrm{YR} 4 / 6$ & 15 & 57.8 & 27.3 & 655 & 149 & 196 & 4.5 & 0.4 & 0.3 & 0.7 & 0.9 & 2.3 & 4 & 17.9 & 1.3 \\
\hline & & Bcf2 & $\begin{array}{l}59- \\
100 \\
\end{array}$ & $10 \mathrm{YR} 4 / 6$ & 21 & 46.9 & 31.8 & 610 & 148 & 242 & 4.6 & 0.9 & 0.4 & 1.3 & 0.7 & 2.6 & 4.5 & 28.3 & 1.2 \\
\hline \multirow{3}{*}{2} & \multirow{3}{*}{$\begin{array}{c}\text { Typic } \\
\text { Lad with } \\
\text { plinthite }\end{array}$} & A & $0-19$ & 7,5 YR 4/4 & - & - & - & 730 & 89 & 181 & 4.9 & 1.26 & 0.07 & 1.3 & 0.4 & 1.8 & 3.6 & 37.2 & 1.5 \\
\hline & & $\mathrm{AB}$ & $19-45$ & 7,5 YR 4/4 & - & - & - & 745 & 104 & 151 & 4.6 & 0.7 & 0.04 & 0.7 & 0.8 & 0.7 & 2.2 & 33 & 1.2 \\
\hline & & $\mathrm{Bw}$ & $\begin{array}{c}45- \\
100+\end{array}$ & 7,5 YR 4/6 & - & - & - & 670 & 119 & 211 & 4.5 & 0.38 & 0.02 & 0.4 & 1.1 & 1.1 & 2.7 & 15.1 & 0.8 \\
\hline \multirow{3}{*}{2} & \multirow{3}{*}{ Typic Lad } & A & $0-21$ & $10 \mathrm{YR} 3 / 4$ & - & - & - & 715 & 104 & 181 & 4.7 & 0.8 & 0.2 & 0.9 & 0.5 & 1.5 & 2.9 & 31.5 & 1.2 \\
\hline & & $\mathrm{AB}$ & $21-38$ & 10 YR $5 / 4$ & - & - & - & 700 & 104 & 196 & 4.6 & 0.5 & 0.1 & 0.6 & 0.8 & 0.8 & 2.2 & 26.2 & 0.8 \\
\hline & & $\mathrm{Bw}$ & $\begin{array}{l}38- \\
100\end{array}$ & 10 YR $6 / 6$ & - & - & - & 640 & 118 & 242 & 4.6 & 0.3 & 0.1 & 0.4 & 0.9 & 1.4 & 2.7 & 14.2 & 0.7 \\
\hline 3 & Typic FFlf & $\mathrm{Ac}$ & $0-11$ & 10 YR 4/4 & 32 & 12 & 56 & 836 & 30 & 134 & 5 & 0.6 & 0.1 & 0.7 & 0.6 & 2.4 & 3.6 & 18.5 & 3.9 \\
\hline \multirow{3}{*}{3} & \multirow{3}{*}{$\begin{array}{l}\text { Petroplinthic } \\
\quad \text { Lad }\end{array}$} & A & $0-22$ & $10 \mathrm{YR} 4 / 4$ & - & - & - & 730 & 89 & 181 & 5.1 & 1.2 & 0.2 & 1.4 & 0.3 & 2 & 3.6 & 38 & 1.4 \\
\hline & & $\mathrm{AB}$ & $22-52$ & $10 \mathrm{YR} 4 / 6$ & - & - & - & 670 & 103 & 227 & 4.6 & 0.7 & 0.1 & 0.8 & 0.8 & 1 & 2.5 & 31.1 & 0.8 \\
\hline & & $\mathrm{Bw}$ & $\begin{array}{c}52-92 \\
+ \\
\end{array}$ & 10 YR 6/8 & - & - & - & 610 & 133 & 257 & 4.6 & 0.6 & 0.1 & 0.6 & 0.8 & 0.8 & 2.3 & 27.6 & 0.7 \\
\hline & \multirow{3}{*}{ Typic FFc } & Ac & $0-18$ & 7,5 YR 3/4 & 15 & 71.6 & 13.7 & 730 & 104 & 166 & 4.8 & 1.1 & 0.2 & 1.3 & 0.4 & 2.4 & 4 & 31.3 & 1.6 \\
\hline \multirow{2}{*}{4} & & $\mathrm{Bc}$ & $18-47$ & 7,5 YR 4/6 & 21 & 55.6 & 23.5 & 700 & 119 & 181 & 4.6 & 0.4 & 0.2 & 0.6 & 0.9 & 2 & 3.5 & 17 & 1.1 \\
\hline & & $\mathrm{Bfc}$ & $\begin{array}{c}47-90 \\
+\end{array}$ & 7,5 YR 5/8 & 11 & 58.3 & 31.1 & 610 & 148 & 242 & 4.6 & 0.4 & 0.1 & 0.4 & 1.1 & 1.7 & 3.2 & 13.8 & 0.5 \\
\hline \multirow{3}{*}{4} & \multirow{3}{*}{ Typic FFc } & Ac & $0-19$ & 7,5 YR 3/4 & 67 & 19.6 & 13.1 & 610 & 163 & 227 & 4.9 & 4.1 & 0.4 & 4.5 & 0.1 & 5 & 9.6 & 46.7 & 9.1 \\
\hline & & $\mathrm{Bc}$ & $19-42$ & 7,5 YR 4/6 & 51 & 11.4 & 37.9 & 730 & 134 & 136 & 4.7 & 0.9 & 0.2 & 1.1 & 0.6 & 1.4 & 3.1 & 35.1 & 2.6 \\
\hline & & $\mathrm{Bcf}$ & $\begin{array}{c}42-90 \\
+\end{array}$ & 7,5 YR 5/8 & 52 & 24.6 & 23.9 & 580 & 178 & 242 & 4.7 & 1.3 & 0.2 & 1.5 & 0.7 & 1.6 & 3.7 & 39.4 & 1.1 \\
\hline \multirow{2}{*}{5} & Petroplinthic & A & $0-18$ & 7,5 YR 4/4 & - & - & - & 745 & 119 & 136 & 4.6 & 0.6 & 0.1 & 0.7 & 0.8 & 1.8 & 3.3 & 20.3 & 1.9 \\
\hline & $\mathrm{Lad}$ & $\mathrm{Bw}$ & $18-68$ & 7,5 YR 4/6 & - & - & - & 580 & 239 & 181 & 4.5 & 0.5 & 0.2 & 0.7 & 0.8 & 1.4 & 2.9 & 22.9 & 0.9 \\
\hline \multirow{3}{*}{5} & \multirow{3}{*}{ Typic FFc } & Ac & $0-22$ & 7,5 YR $3 / 2$ & 21 & 61.5 & 17.1 & 760 & 44 & 196 & 4.7 & 1 & 0.3 & 1.3 & 0.6 & 3.9 & 5.8 & 22.5 & 5.3 \\
\hline & & $\mathrm{Bc}$ & $22-61$ & 7,5 YR 5/6 & 6.3 & 71.1 & 22 & 670 & 119 & 211 & 4.7 & 0.6 & 0.2 & 0.8 & 0.7 & 1.8 & 3.3 & 24.5 & 0.9 \\
\hline & & $\mathrm{Bfc}$ & $\begin{array}{c}61- \\
110+\end{array}$ & $5 \mathrm{YR} 5 / 8$ & 3.6 & 59.2 & 37.2 & 520 & 102 & 378 & 4.7 & 0.8 & 0.15 & 0.9 & 1.4 & 1.6 & 3.9 & 23.9 & 0.8 \\
\hline
\end{tabular}

*F = fragments; Hzn = horizon; $\mathrm{Pe}=$ pebbles $(\%) ; \mathrm{Gr}=$ gravel $(\%) ; \mathrm{FADE}=$ fine air-dried earth $(\%) ; \mathrm{sa}^{2} \mathrm{sand}\left(\mathrm{g} \mathrm{kg}{ }^{-1}\right) ; \mathrm{s}=\mathrm{silt}\left(\mathrm{g} \mathrm{kg} \mathrm{kg}^{-1}\right) ; \mathrm{cl}=$ clay $(\mathrm{g} \mathrm{kg}-1) ; \mathrm{pH}\left(\mathrm{H}_{2} \mathrm{O}\right) ; \mathrm{Ca}^{2+}+\mathrm{Mg}^{2+}\left(\mathrm{cmol}_{\mathrm{c}} \mathrm{dm}^{-3}\right) ; \mathrm{K}+=$ potassium $\left(\mathrm{cmol}_{\mathrm{c}} \mathrm{dm}^{-3}\right) ; \mathrm{S}=\operatorname{sum}$ of bases $\left(\mathrm{cmol}_{\mathrm{c}} \mathrm{dm}^{-3}\right) ; \mathrm{Al}^{3+}=\mathrm{aluminium}\left(\mathrm{cmol}_{\mathrm{c}} \mathrm{dm}^{-3}\right)$; $\mathrm{H}^{+}=$hydrogen $\left(\mathrm{cmol}_{\mathrm{c}} \mathrm{dm}^{-3}\right) ; \mathrm{T}=$ cation exchange capacity $\left(\mathrm{cmol}_{\mathrm{c}} \mathrm{dm}^{-3}\right) ; \mathrm{V}=$ base saturation $(\%) ; \mathrm{P}=$ phosphorus $\left(\mathrm{mg} \mathrm{dm}^{-3}\right) ; \mathrm{FFlf}=\mathrm{Lithoplintic}$ Petric Plinthosol; FFc = concretionary Petric Plinthosol; LAd = dystrophic Yellow Latosol

of the map indicate the highest concentration of those variables that make up the factor, and the darker areas the opposite (Figure 1). This result may be associated with altimetric variation. Nascimento (2012) suggested the existence of transfer areas starting at an elevation of $200 \mathrm{~m}$. In this case, the region under study is a transfer area for sandstones and limestones, the main sources of sediments and solutions transported by the river Cuiabá, which influences the spatial distribution of the chemical variables of soil in the ecotone. Just as in the area under study (soils between the Cerrado and the Pantanal, in a region of ecotone presenting concretionary Petric Plinthosols, an altitude between 180 and $200 \mathrm{~m}$ ), high levels of $\mathrm{Ca}^{+2}$ were identified of $2.61 \mathrm{cmol} \mathrm{dm}^{-3}$, with little variation in concentrations of $\mathrm{Mg}^{2+}$ in relation to the concentration of $\mathrm{Ca}^{+2}$, such that the authors affirm a 
Table 3 - Correlations and variance for the physical, chemical and hydraulic properties of the topsoil and the four axes of the factor analysis. Correlations with $\mathrm{r}>0.6$ are in bold type

\begin{tabular}{lrrrr}
\hline \multirow{2}{*}{ Soil attribute } & \multicolumn{4}{c}{ Principal factor } \\
\cline { 2 - 5 } & \multicolumn{1}{c}{2} & \multicolumn{1}{c}{3} & \multicolumn{1}{c}{. } \\
\hline CEC & $\mathbf{0 . 9 5 9}$ & 0.137 & -12 & -0.113 \\
H & $\mathbf{0 . 8 9 6}$ & 0.231 & -0.21 & -0.122 \\
OM & $\mathbf{0 . 8 5 7}$ & 0.294 & 0.2 & -0.062 \\
K & $\mathbf{0 . 7 7}$ & 0.17 & 0.186 & -0.178 \\
P & $\mathbf{0 . 7 4 2}$ & 0.348 & 0.218 & -0.001 \\
Mg & $\mathbf{0 . 7 2 6}$ & -0.005 & 0.576 & -0.023 \\
Ca & $\mathbf{0 . 7 0 1}$ & 0.065 & 0.597 & -0.079 \\
Mn & $\mathbf{0 . 6 7 0}$ & 0.336 & 0.365 & -0.045 \\
PWP & -0.277 & $\mathbf{- 0 . 8 4 7}$ & -0.122 & 0.239 \\
Pebble & 0.362 & $\mathbf{0 . 7 9 9}$ & 0.194 & -0.226 \\
Gravel & 0.480 & $\mathbf{0 . 7 6 5}$ & 0.058 & 0.065 \\
Clay & 0.098 & $\mathbf{- 0 . 6 4 3}$ & -0.250 & -0.343 \\
pH & 0.136 & 0.211 & $\mathbf{0 . 9 0 7}$ & -0.04 \\
Al & -0.212 & -0.290 & $\mathbf{- 0 . 8 5 5}$ & -0.108 \\
PAW & -0.091 & 0.024 & -0.04 & $\mathbf{0 . 9 5 7}$ \\
FC & -0.116 & 0.107 & -0.051 & $\mathbf{0 . 9 5 4}$ \\
Variance $(\%)$ & 40.49 & 12.37 & 9.99 & 7.76 \\
Accumulated variance $(\%)$ & 40.49 & 52.86 & 62.85 & 70.61 \\
\hline
\end{tabular}

Table 4 - Aggregation index (Ia) of soil attributes for each fragment, obtained by spatial pattern analysis (SADIEShell)

\begin{tabular}{llllll}
\hline \multicolumn{1}{c}{ Factor } & 1 & 2 & 3 & 4 & 5 \\
\hline 1 (CEC, H, OM, K, P, Mg, Ca e Mn) & $1.45^{*}$ & $1.31^{* *}$ & $0.89^{*}$ & $0.80^{*}$ & $1.62^{* *}$ \\
2 (PWP, pebble, gravel, clay) & $2.52^{* *}$ & $1.50^{*}$ & $1.29 *$ & $0.99^{*}$ & $1.20^{*}$ \\
$2(\mathrm{pH}, \mathrm{Al})$ & $1.64^{* *}$ & $1.23^{*}$ & $0.81^{*}$ & $0.97^{*}$ & $1.26^{*}$ \\
$4(\mathrm{PAW}, \mathrm{FC})$ & $1.09^{*}$ & $0.80^{*}$ & $0.91^{*}$ & $1.33^{*}$ & $1.01^{*}$ \\
\hline
\end{tabular}

$\mathrm{Ia}=1$ and $\mathrm{p}>0.05$ indicate random distribution*; Ia $>1 \mathrm{e} \mathrm{p}<0.05$ indicate aggregated spatial distribution $* *$

possible influence from limestone or laterite (MARTINS et al., 2006).

For factors 2 and 3, the higher the proportion of gravel and pebbles, the lower the values for PWP and clay, and the higher the values for $\mathrm{Al}$, the lower for $\mathrm{pH}$ (Table 3). Factor 4 (PAW, FC) is associated with the hydrological characteristics of the soil, indicating an increase in water availability at field capacity (Table 3). The spatial distribution of factor 2 (PWP, pebble, gravel, clay) and factor $3(\mathrm{pH}, \mathrm{Al}$ ) was aggregated for fragment 1 and random for the other four fragments (Table 4). Factor 4 is randomly distributed in four of the five fragments analysed (Table 4).
Random distribution is defined by intrinsic soil properties such as biological factors and differences in hydrology. Spatial dependence, observed in aggregate distribution, may occur depending on the terrain and source material (CAMPOS et al., 2007). In the case under study, this condition may be related to the concretionary and lithoplinthic classes of soil, both Plinthosols and Petroplinthic Latosols, characterised by the large amount of stone concretion throughout the profile (LACERDA; BARBOSA, 2012).

When comparing the surface horizon of the soil, different and/or similar values were identified among fragments for all constituent variables of each factor, 
Figure 1 - Contour maps generated by kriging. Spatial distribution for factor 1: CEC, H, OM, K, P, Mg, Ca, Mn (+). Shading indicates zones of greater and lesser aggregation of the factor. Values $>1.0$ indicate groups of aggregates; values $<1.0$ indicate one or no aggregate. Light areas: greater intensity along the axis; dark areas: predominance of the opposite condition. $\mathrm{F}=$ fragments of Cerrado; $\mathrm{X}$ axis = latitude, $\mathrm{y}$ axis = longitude; DATUM: SAD 69; UTM ZONE: $21 \mathrm{~L}$

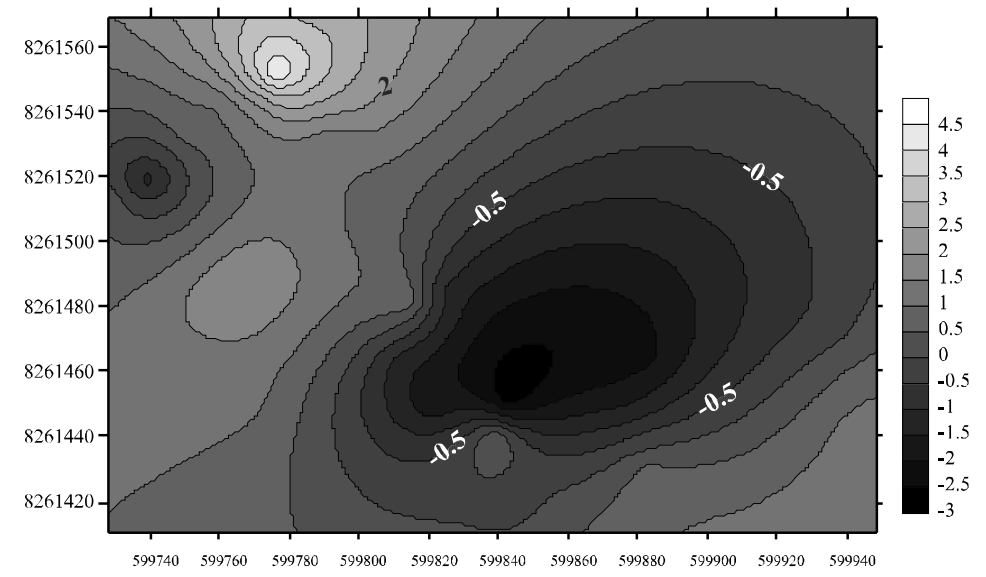

(F1)

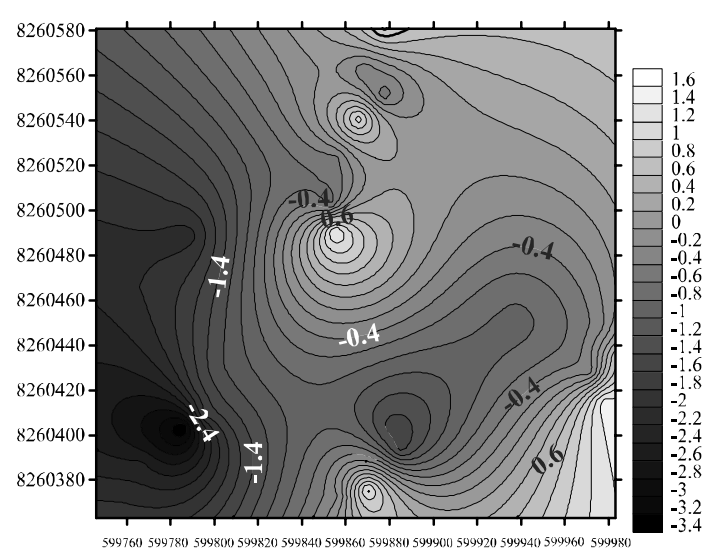

(F2)

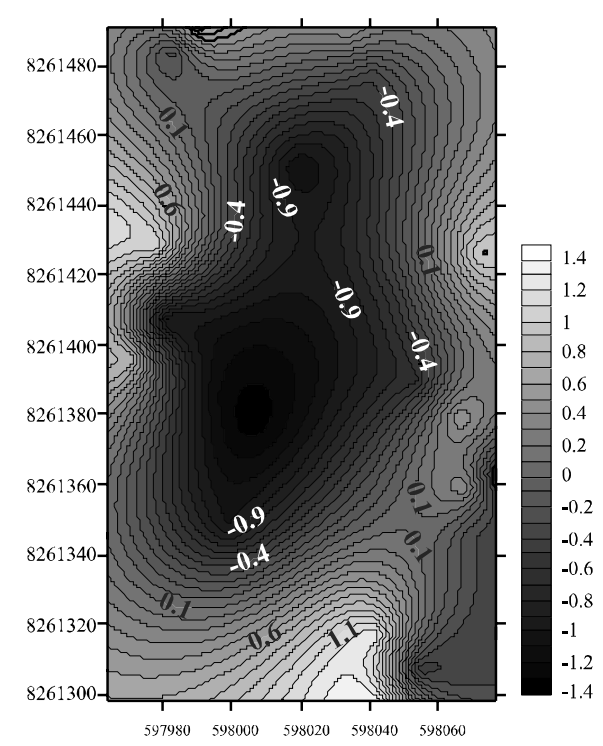

(F4)

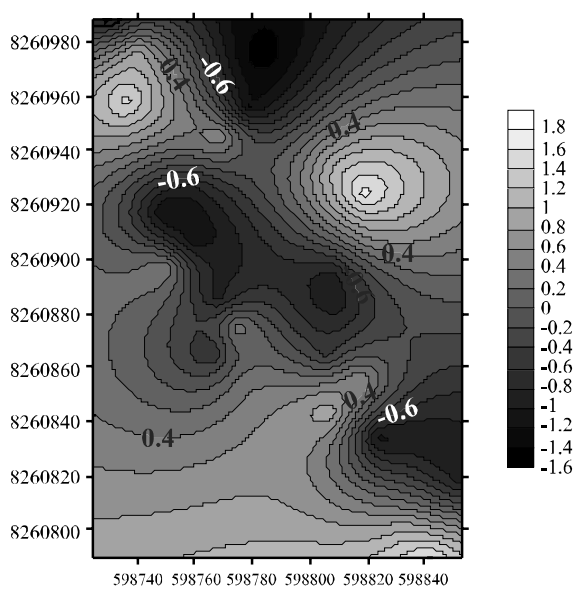

(F3)

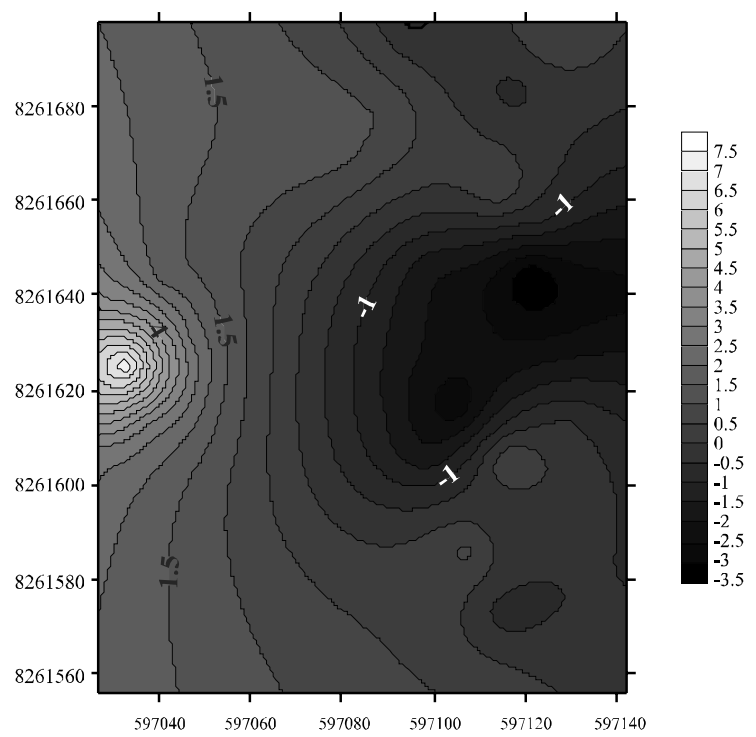

(F5) 
demonstrating the variability of the attributes under study in an area of ecotone (Table 5).

In comparing soils in the Cerrado-Pantanal ecotone (Table 5) with areas of Cerrado of the Plateau and Plains, the mean values for each variable were considered. Those variables which were similar to the soils of the Pantanal Plain were CEC, K, Ca and Mg (Table 5). Despite the CEC ranging from $3.26+0.87$ to $6.49+2.85$ and the average CEC recorded being $4.54+2.16 \mathrm{cmol}_{\mathrm{c}} \mathrm{dm}^{-3}$ in the ecotone (Table 5), these values were similar to those identified for the Pantanal Plain, where average values ranged from $3.91+0.38$ to $14.41+1.00 \mathrm{cmol} \mathrm{dm}^{-3}$ (BEIRIGO, 2008; FERREIRA JUNIOR, 2009). These values are lower than those identified for the Plateau (NERI et al., 2012), probably due to changes in soil mineralogy in the ecotone under study.

For potassium an average content of $>0.15$ cmol $\mathrm{dm}^{-3}$ was recorded, which represents $57 \%$ of the soil samples (Table 5), different from that observed by Lopes and Cox (1977) in which only $14.1 \%$ of the soil samples from the Cerrado of the Central Plateau presented $>0.15 \mathrm{cmol}_{c} \mathrm{dm}^{-3}$. The average levels of magnesium and calcium were predominantly similar or lower than those found for plant physiognomies of the
Pantanal Plain (BEIRIGO, 2008; NASCIMENTO, 2012) displaying values typical of floodplains, and greater than those recorded for plant physiognomies of the Cerrado of the Central Plateau (NERI et al., 2012).

The chemical variables $\mathrm{Al}, \mathrm{Mn}$ and $\mathrm{P}$, as well as field capacity and plant available water, were similar to those identified for the Plateau (LOPES; COX, 1977; NERI et al., 2012). The soils fall into the sandy and medium textural classes (Table 5), similar to Plateau soils under different plant types (ASSIS et al., 2011; GOMES et al., 2004) and different in relation to the wetland plains, where the soils tend to be more clayey (BEIRIGO, 2008; SCHIAVO et al., 2010.).

For those variables which were similar in soils of both the Plateau and wetland plains, average values for organic matter, $\mathrm{pH}$ and soil skeleton were found (ASSIS et al., 2011; LOPES; COX, 1977; NERI et al., 2012; SALIS et al., 2006; SHINZATO; TEIXEIRA; MARTINS, 2006). The predominance of soils with medium acidity and pH near 5.0 (LOPES; COX, 1977) was seen in the fragments studied (Table 5). Variations in the coarse soil fraction, made up of pebbles and gravels, differed depending on soil class. The presence of this material is due to gravel deposits originating

Table 5 - Mean values and standard deviation for the attributes of topsoil. Letters indicate differences between mean values $(\mathrm{p}<0.05)$

\begin{tabular}{|c|c|c|c|c|c|c|c|}
\hline \multirow{3}{*}{ Factor } & \multirow{3}{*}{$\begin{array}{l}\text { Attribute } \\
\text { of the } \\
\text { topsoil }\end{array}$} & \multicolumn{6}{|c|}{ Fragments } \\
\hline & & 1 & 2 & 3 & 4 & 5 & $\begin{array}{l}\text { Average for the } \\
\text { fragments }\end{array}$ \\
\hline & & FFlf & Lad & Lad+ FFlf & $\mathrm{FFc}$ & $\mathrm{Lad}+\mathrm{FFc}$ & FFlf + FFc + Lad \\
\hline \multirow{8}{*}{1} & CEC & $4.97+2.02 \mathrm{a}$ & $3.26+0.87 b$ & $3.9+1.19 \mathrm{ab}$ & $6.49+2.85 c$ & $4.02+1.8 \mathrm{ab}$ & $4.54+2.16$ \\
\hline & $\mathrm{H}$ & $3.29+1.43 \mathrm{a}$ & $1.69+0.65 b$ & $2.10+0.62 c$ & $3.12+1.28 \mathrm{a}$ & $2.34+1.04 \mathrm{c}$ & $2.51+1.21$ \\
\hline & $\mathrm{OM}$ & $17.34+9.7 \mathrm{a}$ & $11.53+3.39 b$ & $11.50+4.32 b$ & $24.62+11.09 c$ & $15.47+6.21 \mathrm{ab}$ & $16.09+8.9$ \\
\hline & $\mathrm{K}$ & $0.17+0.8 \mathrm{ac}$ & $0.11+0.04 b$ & $0.13+0.06 \mathrm{ab}$ & $0.23+0.09 c$ & $0.20+0.11 \mathrm{c}$ & $0.17+0.09$ \\
\hline & $\mathrm{P}$ & $4.23+2.89 \mathrm{a}$ & $2.67+1.07 \mathrm{~b}$ & $2.38+0.84 b$ & $6.19+3.36 c$ & $4.04+2.26 \mathrm{a}$ & $3.90+2.65$ \\
\hline & $\mathrm{Mg}$ & $0.44+0.27 \mathrm{a}$ & $0.47+0.15 \mathrm{a}$ & $0.60+0.31 \mathrm{a}$ & $1.04+0.62 b$ & $0.54+0.36 \mathrm{a}$ & $0.62+0.43$ \\
\hline & $\mathrm{Ca}$ & $0.5+0.5 \mathrm{a}$ & $0.60+0.32 \mathrm{a}$ & $0.64+0.64 \mathrm{a}$ & $1.95+1.35 b$ & $0.61+0.49 a$ & $0.86+0.93$ \\
\hline & $\mathrm{Mn}$ & $68.95+42.2 \mathrm{ab}$ & $55.4+27.57 \mathrm{a}$ & $67.41+16.97 b$ & $114.7+26.18 c$ & $67.94+22.95 \mathrm{a}$ & $74.88+34.82$ \\
\hline \multirow[t]{4}{*}{2} & PWP & $2.73+0.87 \mathrm{a}$ & $3.05+0.46 \mathrm{a}$ & $3.14+0.78 \mathrm{a}$ & $1.43+0.96 b$ & $2.22+1.05 \mathrm{c}$ & $2.55+1.04$ \\
\hline & Pebble & $5.25+7.41 \mathrm{a}$ & $1.82+4.49 \mathrm{a}$ & $3.03+6.92 \mathrm{a}$ & $22.75+10.33 b$ & $12.67+10.35 c$ & $9.11+11.26$ \\
\hline & Gravel & $38.80+23.76 a$ & $13.89+21.14 b$ & $15.39+16.3 b$ & $50.51+12.9 \mathrm{a}$ & $45.51+17.34 \mathrm{a}$ & $32.82+24.01$ \\
\hline & Clay & $13.7+4.78 \mathrm{a}$ & $13.83+3.61 \mathrm{a}$ & $17.74+4.58 b$ & $9.77+1.93 c$ & $10.62+2.26 c$ & $13.14+4.56$ \\
\hline \multirow[t]{2}{*}{3} & $\mathrm{pH}$ & $4.98+0.27 \mathrm{a}$ & $5.17+0.23 b$ & $5.08+0.27 \mathrm{ab}$ & $5.50+0.26 c$ & $5.11+0.21 a . b$ & $5.17+0.30$ \\
\hline & $\mathrm{Al}$ & $0.56+0.27 \mathrm{a}$ & $0.39+0.16$ b.d & $0.47+0.24 \mathrm{ab}$ & $0.13+0.14 c$ & $0.34+0.15 \mathrm{~d}$ & $0.38+0.24$ \\
\hline \multirow[t]{2}{*}{4} & $\mathrm{FC}$ & $9.77+2.62 \mathrm{a}$ & $10.98+1.58 \mathrm{a}$ & $10.55+2.44 \mathrm{a}$ & $13.85+13.63 \mathrm{a}$ & $26.40+12.65 b$ & $14.17+10.14$ \\
\hline & PAW & $7.04+1.84 \mathrm{a}$ & $7.92+1.2 \mathrm{a} . \mathrm{b}$ & $7.41+1.84 \mathrm{ab}$ & $12.8+12.86 b$ & $24.18+11.63 c$ & $11.66+9.84$ \\
\hline
\end{tabular}


with the breakdown of quartz veins and young detritallaterite cover, also made up of a concretion layer of stones, to comprise the shallow soil (SHINZATO; TEIXEIRA; MARTINS, 2006). The process of plinthisation occurs in areas which are both susceptible to flooding and where drainage is impeded.

\section{CONCLUSION}

The soils of the study area consist of features which are inherent to Cerrado soils of both the Central Plateau and the Pantanal Plain. The chemical attributes that best explained the variability of the soils of the Cerrado-Pantanal ecotone were CEC, M, $\mathrm{OM}, \mathrm{K}, \mathrm{P}, \mathrm{Mg}, \mathrm{Ca}$ and $\mathrm{Mn}$. The spatial distribution of the attributes varied between random and aggregated for any one set of variables (chemical, physical and hydric), with the chemical attributes CEC, K, Ca and $\mathrm{Mg}$ being identified as similar to the soils of the Pantanal Plain; whereas $\mathrm{Al}, \mathrm{P}$ and $\mathrm{Mn}$, as well as the hydric variables, were similar to the Plateau. On the other hand, the average organic matter content, $\mathrm{pH}$, gravel and pebbles, were characteristic of both the Plateau and the Plains. Thus, the identification of different soil types in the same region, associated with different types of spatial distribution, as well as the differentiation of attributes which are either specific to the Pantanal or to the Cerrado, or similar to both, is characteristic of the edaphic heterogeneity of the Cerrado-Pantanal ecotone.

\section{ACKNOWLEDGEMENTS}

The authors wish to thank the National Council for Scientific and Technological Development (CNPq) for the doctoral grant awarded to the first author. Thanks also go to Dr Clovis Miranda for contributing to the collection and analysis of the data.

\section{REFERENCES}

ASSIS, A. C. C. et al. Water availability determines physiognomic gradient in an area of low-fertility soils under Cerrado vegetation. Plant Ecology, v. 212, n. 7, p. 11351147, 2011.

BEIRIGO, R. M. Sistema pedológico PlanossoloPlintossolo no Pantanal de Barão de Melgaço - MT. 2008. 69 f. Dissertação (Mestrado em Solos e Nutrição de Plantas) - Escola Superior de Agricultura "Luiz de Queiroz", Universidade de São Paulo, Piracicaba, 2008.
CAMPOS, M. C. C. et al. Variabilidade espacial da textura de solos de diferentes materiais de origem em Pereira Barreto, SP. Revista Ciência Agronômica, v. 38, n. 2, p.149-157, 2007.

CASTRO JUNIOR, P. R.; SALOMÃO, F. X. T.; BORDEST, S. M. L. Geomorfologia. In: THOMÉ FILHO, J. J. et al. Sistema de Informação Geoambiental de Cuiabá, Várzea Grande e Entorno - SIG CUIABÁ. Goiânia: CPRM, 2006. p. 3-48.

COUtinho, L. M. O conceito de Cerrado. Revista Brasileira de Botânica, v. 1, p. 17-23, 1978.

DUNIWAY, M. C.; BESTELMEYER, B. T.; TUGEL, A. Soil process and properties that distinguish ecological sites and states. Rangelands, v. 32, n. 6, p. 9-15, 2010.

EMPRESA BRASILEIRA DE PESQUISA AGROPECUÁRIA. Centro Nacional de Pesquisa de Solos. Manual de métodos de análise de solo. 2. ed. Rio de Janeiro, 1997. 212 p.

EMPRESA BRASILEIRA DE PESQUISA AGROPECUÁRIA. Centro Nacional de Pesquisa de Solos. Sistema brasileiro de classificação de solos. 2. ed. Rio de Janeiro, 2006. 306 p.

FERREIRA JUNIOR, W.G. Análise de gradientes vegetacionais e pedogeomorfológicos em Floresta, Cerrado e Campo no Pantanal mato-grossense, Barão de Melgaço, Mato Grosso. 2009. 178 f. Tese (Doutorado em Ciências) - Universidade Federal de Viçosa, Viçosa, 2009.

GREIG-SMITH, P. Quantitative plant ecology. Berkeley: University of California, 1983. 359 p.

GOMES, J. B. V. et al. Análise de componentes principais de atributos físicos, químicos e mineralógicos de solos do Bioma Cerrado. Revista Brasileira de Ciência do Solo, v. 28, n. 1, p. 137-153, 2004.

KARK, S.; VAN RENSBURG, B. J. Ecotones: marginal or central areas of transition? Israel Journal of Ecology and Evolution, v. 52, n. 1, p. 29-53, 2006.

KÖPPEN, W.; GEIGER, R. Klimate der Erde. Gotha: Verlag Justus Perthes, 1928. LACERDA, M. P. C.; BARBOSA, I. O. Relações Pedomorfogeológicas e Distribuição de Pedoformas na Estação Ecológica de Águas Emendadas, Distrito Federal. Revista Brasileira de Ciência do Solo, v. 36, n. 3, p. 709721, 2012.

LOPES, A. S.; COX, F. R. A survey of the fertility status os surface soils under Cerrado vegetation in Brazil. Soil Science Society of America Journal, v. 41, n. 4, p. 742-747, 1977.

MARTINS, A. K. E. et al. Relações solo-geoambiente em áreas de ocorrência de Ipucas na Planície do Médio Araguaia - Estado de Tocantins, Revista Árvore, v. 30, n. 2, p. 297 310, 2006.

NASCIMENTO, A. F. Relações pedologia-geomorfologiasedimentologia no Pantanal Norte. 2012. 200 f. Tese (Doutorado em Ciências/Solos e Nutrição de Plantas) - Escola Superior de Agricultura Luiz de Queiroz, Universidade de São Paulo, Piracicaba. 2012.

NERI, A. V. et al. The influence of soils on the floristic composition and community structure of an area of Brazilian 
Cerrado vegetation. Edinburgh Journal of Botany, v. 69, n. 1, p. 1-27, 2012.

POOR, A. et al. Do physiological integration and soil heterogeneity influence the clonal growth and foraging of Schoenoplectus pungens? Plant Ecology, v. 181, n. 1, p. 4556, 2005.

POSSLEY, J.; WOODMANSEE, S. W.; MASCHINSKI, J. Patterns of Plant Composition in Fragments of Globally Imperiled Pine Rockland Forest: Effects of Soil Type, Recent Fire Frequency, and Fragment Size. Natural Areas Journal, v. 28, n. 4, p. 379-394, 2008.

PROJETO DE DESENVOLVIMENTO AGROAMBIENTAL DOESTADO DE MATO GROSSO. Mapa de reconhecimento de baixa intensidade dos solos e pontos amostrais - MIR 388. 2001. 1 Mapa. Escala 1: 250.000.
SALIS, S. M. et al. Distribuição e abundância de espécies arbóreas em cerradões no Pantanal, Estado do Mato Grosso do Sul, Brasil. Revista Brasileira de Botânica, v. 29, n. 3, p. 339-352, 2006.

SCHIAVO, J. A. et al. Caracterização e classificação de solos desenvolvidos de arenitos da formação Aquidauana-MS. Revista Brasileira de Ciência do Solo, v. 34, p. 881-889, 2010.

SHINZATO, E.; TEIXEIRA, W. G.; MARTINS, J.S. Solos. In: THOMÉ FILHO, J. J. et al. Sistema de Informação Geoambiental de Cuiabá, Várzea Grande e Entorno - SIG CUIABÁ. Goiânia: CPRM, 2006. p. 117-161.

ZEITHAML, J.; PIŽL, V.; SKLENICKA, P. Earthworm assemblages in an ecotone between forest and arable fi eld and their relations with soil properties. Pesquisa Agropecuária Brasileira, v. 44, n. 8, p. 922-926, 2009. 